connexion be noted that, going through the lock, as I generally did alone, it was easy for me to regulate the taps to meet my own comlort; but when thirty men went through together it is probable that the tympanic membranes in some of them were conslderably stretched.

In the matter of decompression there was no discomfort at all, and therefore; as far as the men could understand, there was no reason why this process should be prolonged, especially as they were packed like herringssometimes thirty-two men In a space of 470 cubic feet. It only requlred one devil-may-care man to get In charge of the tap, turn it on to Its full capacity, and bring them all through at a dangerous rate. I have been decom. pressed myself-a foreman at the tap-at the rate of one and three-quarter minutes for $15 \mathrm{lb}$, and this in face of $\mathrm{my}$ ingtruction that the decompression rate of one minute for every 5 lb. should be enforced. As a matter of laot, the conditions in the lock were so unpleasant-a confined space, no seats, a dense vapour, and overcronding - that every minute seemed like five. To reduce the number of men entering the lock from thirty-two to sixteen was $a$ matter of no small difficulty, and caused some felction. Further, one of the principal officlals informed me "he thought that decompression should be conducted as quickly as it could be done." This opinion he was, of course, unable to support by any convincing resson, but no doubt the expression of such a view would largely influence the workmen if he opened his mind to them as freely as he did to me.

For this, that, and the other reason, decompression was conducted at too rapld a rate if our present knowledge of the subject is correct-a danger that can only in practice be avolded by providing larger, more numerous, and more comlortable locks, these being fitted with taps carefully tlmed. Taps might even be made to conduct the graduated atage decompression recommended by ifaldane, but the great practlcal difficulty is found in the workman himsell.

I select a few of the more interesting cases, in the hope that, even with all their imperfections, the notes may be of some value to those studying the subject.

Case I.

A. F., aged 36, entered the tunnel-then ander a pressure of about $16 \mathrm{lb}$. - st 6 a.m., worked as usual till 2.30 p.m., and came out. He had left the lock about ten minutes when he was selzed with acute pain in the abdomen, knees, and ankles. He re-entered the tunnel, and Immedistely felt quite well ; he asserted that he "instinotively felt" that such a relief would be obtalned. He walked about for an hour, and, belleving himale to bo all right, ho pagaed through tho look agaln. On himsolf to bo all right, ho passod through tholock agalb. his way home the pains returned, causing him to retrace his steps for recompression; whioh this time relieved the abdominal pain, bat left the pains in the knees and ankles nnmitigafed. At this stage he was examined, ergotin was injected, and he was placed in the medical lock under a pressure of 60 and compressible, the temperature normal, the tonga clesn, and the glgns in jolnts negative; the superficial voing in the lege were somewhet oongested, and there was Impaired maintained for half an hour, and elowly reduced. The sensation he then declared to be normal, but the legs were still numb. As he llved close at hand he started, belween two of his mates, to walk home, refusing the ald of a cab or other conveyance. He dragged his right foot, eventually ostohing it behind the left heel, and would have fallen if unsapported.

Seen at his home next morning, his pulse was 60 and the temperature normal. The paresis of the legs wes more marked in the right, the superficlal veins were still congested, the rlght leg was markedly dragged, sensation to pin-pricks the right leg was markedly dragged, eensation to pin-prick jerks were exaggerated, especlally in the right leg; the heart jorks were exaggerated, especial no wigne of syphilis or other soands were normal ; the

constitutional disease:
He was confined to his home for ten days, and then got soout with the aid of sticks, but with great difficulty, his right leg stlll dragging. As massago and faradism failed to improve this state of affairs, he was admitted to the Hospital for Epllepsy and Paralysis on December 21st, 1906, threo monthe from the date of his attack. Heloft tho ing months from December When examined on Jane 1st, 1907, he was still obliged to ase generally in the right leg and the limb was still dragged to some extent.

I glve this case as one to my mind typlcal of compressedair lilness, and It was at the same tlme the most serlous ol those that came under my notice.
CASE II.

G. 8., aged 45 , on July 16th, 1907, on rising from bed at $4.30 \mathrm{s.m}$. experienced a slight pain in his left hip. He went to work, and seemed worse on passing through the lock Into the to work, and seemed worse on passing through the lock into the home. As there was no improvement during the das, he returned to the worke, and was placed in the medical look under a pressure of $16 \mathrm{lb}$., which was allowed to leak out. This was repeated several times, with complete relief, but the pain: returned on the way home.

The knee-jerks were slightly exaggerated and the left leg dragged; there were no other signs. Pain was a marked symptom, and was not referred in thls case to the knee, the usuel sest but to the hlp and ankle. for a fortnight, and then resumed work. He had worked in compressed air for manj years at both high and low pressures compressed air for manj years at both high and low pressures, to return to the compressed air, but he did so and remsined well.

Casm III.

E. T. W., aged 36, on Angust 2nd, 1907, left' the tunnel in his usual health, but wes gelzed with pain in his back ond lege before he reached home. He passed a sleepless night. Beyond exaserated knee-jerks and snkse clonus his signs were nega exaggerated knee-jerks and ankle clonus his slgns were nega-
tive, bat, his pains persisting, he was sent into the loosl tive, bat, his pains persisting, he was sent into the local infirmary and was treated there and by me for over two months. On Ootober 14th he re-entered the compressed air in defience of warning, and was eimilarly attacked on October 16th. The relapse lasted a month, and, while the signs and symptoms were apparent effect on his initial seizare.

Cash Iy.

F. B., aged 34, on May 22nd, 1907, was selzed on his return from work with severe pains in the legs, back, shoulders, and elbows. His signs and symptoms were similar to those of the cases alread oited, and he dragged his right leg for some ten days. This case was singular in the respect that he had pain above the waist.

Cases in which pain in the legs lasted a few days were of dally occurrence, and were called by the workers "an attack of the bends"; they were entirely subjectlve in character, and one attack did not seem to preclispose to another. A lew cases of pain in the testlcles came under my notice, but beyond the physical distress they showed nothing worth recording.

Conducting the medical charge of this great engineering work In conjunction, as I did, with many other dutles, I fear the opportunities for studying compressed-air illness were much neglected, and it may be long betore as large an area is again enclosed. In a confined apace the elements which go to make up this interesting and curious condition are not to be found. There were many fewer cases of compressed-air lliness in the Rotherhithe Tunnel than in the Blackwall, and I certainly think our efforts to produce a better sanitation and a longer period of decompression met with a measure of success.

Since writing the above I have enjosed the pleasure and instruction of reading the able lecture by Dr. Greenwood, reproduced in the columns of the BrITISH Mrdicar. JoURNAI, and I much regret that $I$, being Ignorant of the fact that he was conducting these experiments, took no steps to bring hls theory and my opportunlty for practice into line. I was uniformly decompressed at an average rate of lour minutes for $16 \mathrm{lb}$. scores of times, and the heads of the contracting firm were treated In the same way every day. Further, I have good reason to sngpect that at the end of the shift the men turned the " much tap," and came out in a time that might be best stated in seconds. If Dr. Greenwood's views are correct, it is quite clear that In futare operations in compressed air, medical arrangements should be made which the men not only may not, but cannot, infringe.

\section{THE MENTALLY DEFECTIVE IN PRISON.}

Bx JNO. MILSON RHODES, M.D., J.P., VISITING JUSTICE OF H.M. PRISON, MANCHESTER.

ThE Inside of our English prisons is to the vast majority of the people a terra incognita. Nevertheless prisons and the prisoners have not received in the past the consideration that their Importance demands, and it is very satisfactory to see that a commission of thoroughly competent gentlemen has been appointed to inquire into the treatment of certain classes of cases, and I venture to say that when the public realize the large percentage of mental 
defectives that are in our prisons the will insist on the law belng altered " to make the punlshment fit the crime" to a greater extent than it does at present. The object of our prisons is not, or, at any rate, ought not to be, simply the punishment of crime, but also the prevention of crime; the treatment should not only inflict retribution, but also deterrence and reform, and the latter should be of fully as great importance as the former, if not more so.

In dealing with the varlous classes of breakers of the law, those who, as Dr. Mercler well says in his work, "have done wrong in the purauit of gratification for themselves by the intentional injury of others " must be firmly dealt with; but before Inflicting punishment we must, as far as we can, reallze the amount of Intention there was In the mind of the offender at the time and how far he was responsible at the time. Only a few years ago a justlce assured me that there were no feeble-minded in gaol. When the report of the Roral Commission on the Feeble minded is publlshed next month not only the public but some justices of the pesce will learn something. That there are a large number of the mentally defective in our prisons is absolutely certain, and it is also certaln that their real mental condition was not diagnosed at the time of their committal.

This is not only my own opinion; at the International Congress at Amsterdam last jear Dr. Morel, of the Mons Asglum, gaid :2

Un très grand nombre de oriminels, surtout des oriminels rócidivistes, présentent des symptômes multiples de l'insni récidivistes, présentent des symptômes multiples de l'insui-

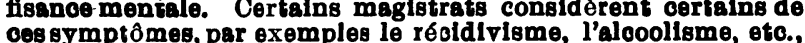
comme de circonstances aggravantes, alors que le psychiatre volt des clrconstances atínuantes au polnt de vue pénale aggravantes an polnt de vae de la proteotion de la soclété es da délinguant.

No doubt the magistrate, like the medical officer of the prison, has to be on his guard against malingerers of all kinds; but when you find that in the last report, out 0 ? a total of 241 criminal lunatics, no less than 162 were certified as such "after conviction," it is very questionable if the law is the embodiment of everything that is excellent. Dr. Donkin, the prison commissloner, sptaking at a conference at Birmingham last November, made the very serious assertion:

The bald statement may be ascepted that the weak-minded amount to between 10 and 15 per cent. of the total number of persons committed to prison; the trae maximum is probably even higher than this.

In another place in the same paper he says :

$O$ wing to their inherited Incespoltles and to certaln surroundinge, a large number of mental defectives tend to becom criminals, and a considersble proportion, even 20 per cent., of so-called criminals or law-breakers are demonstrably mentally defeotive.

The whole of the prison commissloners are evidently of opinion that far-reaching reform is reguired, for in their report for 1905.6 they very plainly state that:

The steady decrease in the rate which has been golng on $f^{r}$ some years is very setisfactory, bat when it is pointed out the of the 129 cases of Insanity certificated in the prisons 73 wer found to be mentally unsound on reception and 27 more exhibted symptoms of insenity within a month of reception, it will be seen there is much need for reform In the matter of committing persons to prisons who are actually Insane or who are on the borderland. Many of those who were in prison for are on the borderiand. Many of those who were in prison for were elther descrlbed as of weak, unstable, or Impaired mentsl condition on reception or were known to have been prevlously insane.

In addition to those certified Insane 354 were reported as more or less unfit for the ordinery penal disclpline owing to mental deficlenoy, and wero treated ander the regulations of the feeble-minded Several of the feeble-minded were recelved more than once in the year, and the records of many of these prisoners indicated the desirsbility of deallng with them in prisoners Indicated the desirability of de日
other weys than sending them to prison.

These are strong expressions, but in my oplnion are thoroughly justified and deserving the most carelul consideration not only by visiting justices but by every maglaterial bench in the country.

Dr. Branthwaite, 4 Home Office Inspector under the Inebriates Act, is very much of the same oplnion. Since the Aot dealing with inebriates was pasged in 1898, 2,277 have been sent to colonles under that Act. Dr. Branthwalte divides them as follows:

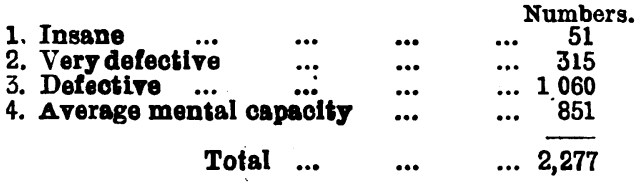

Oat of the 2,277 cases, 1,375-about 63 per cent. - are either totally irresponsible for thalr drunkenness and dranken offences or are only partially responsible for their anfortanate condition, with its resulting evils.

That leaves out of account the 51 cases decldedl Insane. My own experlence of prisoners corroborates Drs. Donkin, Branthwalte, and Morel's view, and a prison governor. with very large experience told me that he belleved that almost all the prisoners who violate the prison regulations are feeble-minded. It must be borne in mind that these grave charges against our prison gystem are brought not by cranks and faddists, but by experienced and responsible alienists, who are the very last people to make unfounded statements. HOW serious the charge against the present atate of the $18 \mathrm{w}$ is. If the charges are true, Is shown by the lact that 183,773 persons were Imprisoned in 1906.

That my estimate of 10 per cent. feeble-minded was 100 low I freely admit. Mr. Henry Wolfer of Minnesota said; at a meeting of the heads of State Institutions, that-

On the borderland of lunsoy lie the oriminal popalation,

and added-

That no more rexed problem comes before the medlcal psyohologist then to determlne where badness ends and madness begins. hundred and seventy-five prisoners there were sixty-elght who were actually Insane at the time of conviotion or Immediately theresiter, and one handred and twenty-two who were degenerate incorrigibles, who ought to be set apart as a clase by themselves and trested ss ouch and thet one-fonrth and possibly one-third of all adult convicts found in State prisors possibly one-third of all

If Mr. Wolfer is right (he has had thirty gearg' ex. perlence) there must be many in our prisons who should not be there, for with a prison popalation of 20,377 on March 318t, 1906, only 955 criminal lunatlcs were in the criminal county and district asplums of England and Wales. That not all the cases were suffering from temporary Insanity is proved by the fact that out of 203 cases of discharged criminal lunatics 112 were "ordered by justice to remsin in asylum."

Any one who will carefully study the judiclal statistics of England and Wales must acknowledge that if we have succeeded in penallaing the delinquent we bave to 8 large extent falled both as to deterrence and reform, the two objects which should be the chlel alm of punishment. Of 182,645 convicted prisoners in 1906 no less than 107,408 had previous convictions agalnst them ; of thesc-

7,458 had been convicted four times.

$\begin{array}{lll}5,612 & \text { " } & \text { five times. } \\ 17,093 & " & \text { six to ten times. } \\ 12,592 & ", & \text { eleven to twenty times. } \\ 10,700 & \text { ", } & \text { above twenty times. }\end{array}$

A system that has falled in 59 per cent. certainly cannot be called a success; the offender has been made a convicted criminal, but he has evidently in all these cases gone out of prison as much at heart a criminal as he came in.

When you find a recldivlst who has stolen a small article of the same description thirty times, surely that man must be to some extent non compos mentis to do such an Idiotic sct.

It is to be feared that we look npon the criminal as much responsible as the average man in the street. He Is not so. The following figures prove that, whatever bis education filay have been morally-il he had ang-he had little intellectually :

Prisoners nelther able to read or write ...

Prisoners able to lread or read and write

imperfectlo

Prisoners of superior educstion

Prisoners' education not ascertalned

144,566

8,857

8,857

The figures show that out of 183,000 prisoners no less than 173,000 had little or no education. If the secterlan educatlonalists who are quarrelling "while Rome burng" wonld only conslder the serlous Importance of those figures, they would see the necessity there is of Impresoing 
upon the young mind the importance of that old doctrine' "Thou shalt not."

Want of education is a powerful cause of mental degeneration; the total neglect of training to appreciate anything approschlng Intellectasl enjoyment is one of the causes of so many seeking the lowest forms of sensual enjoy ment, with all the mental and moral demoralization assoclated therewlth. Ignorance, idleness, and inebrlety are the milestones that mark the victlm's progress on the road to ruln that ends in the asylum, the workhouse, or the prison, wilh such dleastrous results, not only to the unfit, but to the unfortunate ratepayers, who have to bear both the injury done by the prisoners and also the cost of their keep, to say nothing of the loss to the State of their labour.

Now, what do we hope to galn by an alteration of the system?

1. A better classification of prisoners. The thoroughly vicious crimlnal must be taught by experience that the way of tranggressors against the law is hard; but for the weak-minded; the Ignorant, the misled, we want a very different system of classification than we have or can have under the present nystem. For the weak-minded our prlson gystem is tio hard.

2. Our present gystem of provlding for prisoners Is very expensive. For the dangerous crlminal we must provide prisons where the offender can be confined In safety; but for the less serlous offences, such as drunkennfss, petty larceny, etc, the State farm would be far more usefal and remedial.

3. Attached to each prison should be an expert allenlst, as in Belglum, I remember with horror that some jears ago a chronlc eplleptlc was hanged for murder.

4. An alteration of the law as regards the habltual drunkard. As the law stands at present on the statute book, many of the inmates of our inebriate reformatorles are hopeless dipsomanlacs before they arrive. If the ratepayers are to recelve a proper return for thelr money, w' must repeal the law as to convlctions and have the offenders detained under an enactment on the lines of that in force in Massachusetts.

5. It is a debatable question what percentage of the commissioners should be ex.army officers; there should certsinly be more medical ones.

6. That any gystem will sbolish crime I do not belleve but at the present tIme I am afrald our exlsting system of doing things is on the how not to do It system, and I say without hesitation that I am very glad the Commission has been appointed.

Criminal Regponsibility C.MFERENCE

Triminal Responsibility, C. Mercier, clarendon Press, Oxford. 2 I thropique Paris, 3 The Feeble-minded Criminal, M.D Birmingham Education Committee. \& Mentally - defective Drunkards, K. W. Branthwaite, Esq, M.D.

\section{MEMORANDA :}

\section{MEDICAL, SURGICAL, OBSTETRICAL.}

\section{CEREBRAL INFLUENZA.}

I. HAVE read with much Interest Professor Sanndby' address on cerebral Influenza in the Brimise Mrdical JodRAar of June $6: \mathrm{h} ; 1908$, and as he points out that the cases are rare, and in consequence llable to give rise to serlous difficultles in diagnosis, I think it may be of ase to record briffly the notes of a case that came under my care in Janzary last. The patient was a girl aged 23 and was admitted to the R2yal Clty of Dublin Hospital on January $26 \mathrm{th}$, during the helght of the Influenza epldemlc of thls year. On admission she was in a state of deep coma, and was Indeed sent in as a case of probsble cerebral abscess, on account of a slight discharge which was stated to ba coming from the left ear. The only history obtainable was that she had suffered from some sllght gastric disturbance about six weeks prevlously from this she had completely recovered, and remsined in good hesith untll four days prior to admission to hospltal. She then began to complain of general weakness, Inabllity to stand or walk, and of vlolent pains th the head, and vomited once or twice. These aymptoms increased; and on the day belore admilasion ahe beonme delirlcus, falled to rasognlze those around her, and talked Incoherently.' Her temperature at this time was sald to be somewhat raised. On examination the patient was found to be in a state of complete anconsclousness. The puplls were dilated, but reacted to light, and the optlc discs were normsl. The membrana tympani on both sides was normal, and no aural discharge could be detected. The jaws were tightly clenched, the tongue foul and costed, throat normsl. The neck was rigld and slightly retracted; the anterior cervlcal glands somewhat enlarged; heart and lungs normal; abdominal organs normal; well-marked rectus reflex. The gphincters were relaxed, but a catheter specimen of urine showed a slight cloud of albumen without caste. No other abnormal constituents were present. The legs were somewhat rigld, with well-marked knee reflexes and oljght ankle clonus. Neither Kernig's sign nor Babinskl's sign was present. The temperature was $101^{\circ} \mathrm{F}$; pulse 104, and very feeble; respirations, 30 to the minute. A blood examinstion revealed nothing abnormal, the white cell count being only 7,500 per c.mm., with 76 per cent. of granular cells. Some fluid removed by lumbar punctare was quite clear; no bacterla were found elther in smear preparations or on culture in serum tubes. A Widal test proved negative, as did also Calmette's ophthalmo-reac. tion. The patient remained in the above-deacribed condition for four days, and then the temperature sank to normsl, and the coms became less profound, so that she could be slightly rcused. On the six th das she made some attempts to speak, and was able to swallow fluids, and from that on recovery was steady but slow. Up till her discharge from hospltal, four and a half weeks after admiseion, she continued to suffer somewhat from aphasia, finding difficulty apparently in selecting the right words to express herself, and often applying wrong terms to famillar objects. A fortnight later, however, alter a stay in the convalescent home, this symptom bad disappeared, and she was in every way in perfect health. As will be ceen from a ref $f$ rence to Professor Saundby's paper, thls csse corresponds closely with some of those that he describes and therefore requires no further comment. On admission no diagnosis was made (except that the patient was suffering from a prolound toxsemia of the nervous eystem), and it was only by a process of exclusion that the diagnosis of cerebral influenza was arrived at. No drug treatment was ordered, as there was no Indication for any special chemical or serum therapy; Icebags were applled to the head; nutrient enemats were given at first, and carelul watching and nursing were observed.

T. GILLMAN MOORHEAD, M.D , F.R C.P.I., Physician, Royal City of Dublin Hospital.

MRs, J., aged 40, a healthy woman, the mother of three healthy children, the wile of a farmer, had for three or lour days previous to the att3ck complained of headache and chilliness. On April 25th of this year she rose early, and, beyond a headache, was teellng tairly well. She went to feed her chickens, when suddenly she felt faint, and just managed to reach the houge, when she had a "fit." The family sent for me, and on my arrival, about three hours later, I found her. In bed in a condition resembling that of a person recovering from an epileptic fit. She complained of severe headache, persistent vomiting ; temperature normal, palse 65. I was informed that she had had two fits, one on reaching the houge, and another an hour later; during the fits she was unconsclous, formed at the month, and was convulsed. A mixture of bromide of potash and phenazone and a dose of calomel were prescribed, cold was applled to the hesd, and strict rest and quilet were enjolned. The following day she appeared better; the vomiting had ceased, the headache was not so severe, and she seemed more allve to her surroundlngs; she spoke distinctly and readily. She complained of considerable intolerance to light, in the left eye especialjy. On the third day temperature $101^{\circ} \mathrm{F}$, pulse 85; the headache during the night was intense, and she seemed to be snffering greatly with her head. I gave a tablold of $\frac{1}{2}$ grain of morphine with ${ }_{12}^{\frac{1}{2}} \sigma$ atrop. sulph.; thls was followed by some rellef, and she slept for two or three hours Photophobia atill marked. On the morning of the fourth dag the hesdoohe was not so severe; she was more cheerfal; temperstare a little lower. The paln returned with Intensity in the evening and was again relieved by morphine The filth deg, the patlent had slept after the 